\title{
Effects of different approaches on the quality of dahi
}

\author{
A. I. Bhuiyan', A. Wadud ${ }^{1}$, A. Nahar ${ }^{2}$ and M. Al-Amin ${ }^{2}$ \\ ${ }^{1}$ Department Of Dairy Science, Bangladesh Agricultural University, Mymensingh-2202, ${ }^{2}$ Breed Up-gradation Through \\ Progeny Test Project and District Artificial Insemination Center, Barisal, Bangladesh
}

\begin{abstract}
The present research work was undertaken to increase the consistency of dahi or yoghurt on its quality using volume reduction, commercial starch powder and potato mash. In this experiment, five different types of dahi samples were prepared and designated as A (30\% volume reduction), B (990 ml milk $+1 \%$ CSP), C (980 ml milk $+2 \%$ CSP), D (970 $\mathrm{ml}$ milk $+3 \% \mathrm{CSP})$ and $\mathrm{E}(950 \mathrm{ml}$ milk $+5 \%$ potato mash). Quality of dahi was also monitored by using physical, chemical and microbiological tests. From the results of physical study (smell and taste, body and consistency, and colour and texture), it was found that the differences of total score among A, B, C, D and E dahi samples were statistically significant. The mean values of acidity, fat, protein, ash, total Solids, water and $p^{H}$ contents for $A, B, C, D$ and $E$ types of dahi were significantly different $(p<0.01)$. No significant differences were observed for coliform count but significant difference was observed in total viable count. It is suggested that $2 \%$ commercial starch powder dahi could be used successfully to prepare dahi nearly similar to the quality of plain dahi.
\end{abstract}

Keywords: Consistency, Dahi, Commercial starch powder, Potato mash

\section{Introduction}

Dahi is one of the oldest fermented milk-products and is the most popular one in Bangladesh. Yoghurt or dahi is a good source of B vitamins, proteins, and calcium which are much easier for the body to digest than when they are present in fresh milk. Dahi contains $85-88 \%$ water, $5-8 \%$ fat, $3.2-3.4 \%$ protein, 4.6 $5.2 \%$ lactose, $0.5-1.1 \%$ lactic acid, $0.70-0.75 \%$ ash, $0.12-0.14 \%$ calcium and $0.09-0.1 \%$ phosphorous (Laxminarayana et al., 1952). Different types of dahi such as sweet dahi, sour dahi and flavoured dahi are usually found in the market. Shakeel et al. (1994) used successfully mango juice to enrich the quality of sweet dahi. Soya milk and sunflower protein could be used in the manufacture of yogurt (Hardi and Novakovic, 1994). Commercial starch powder (CSP) and potato could be used in preparing dahi and potato contains $77.5 \%$ moisture, $22.5 \%$ total solids, $2 \%$ Protein, $0.1 \%$ fat, $19.4 \%$ carbohydrate, $0.6 \%$ Crude fiber and $1.0 \%$ vitamins, while CSP contains moisture $0.5 \%$ carbohydrate $81 \%$, fat $0.9 \%$, Protein $12.0 \%$ and Ash $0.8 \%$.

Dahi or yoghurt is also effective in lowering the blood cholesterol (Mann and Spoerry, 1974). Traditionally, dahi is made from milk by reducing its volume. By reducing volume of milk producers got loss economically. Heat also facilitates to loss of nutrients like volatile fatty acids, vitamin $\mathrm{C}$ and some fat soluble vitamins through evaporation. They will be economically benefited without reducing volume of milk. The present study was undertaken using potato mash and commercial starch powder for preparation of dahi without reducing volume of milk and to evaluate the quality of dahi.

\section{Materials and Methods}

The experiment was carried out at the Dairy Chemistry and Technology Laboratory of the Department of Dairy Science, Bangladesh Agricultural University, Mymensingh, during the period of August to October, 2008. Chemical analysis was done at the Dairy Technology \& Microbiology Laboratory, the aquaculture Laboratory and the Central Laboratory of Bangladesh Agricultural University, Mymensingh.

\section{Collection of milk samples}

Whole milk was collected from Bangladesh Agricultural University Dairy Farm.

\section{Preparation of potato mash}

The collected potato sample was boiled and after boiling the skin was separated with the help of clean hand. Black spotted if any, were removed from the potato. Then the potato was measured with the help of balance. The measured potato was kept in plastic cups for further study. 


\section{Preparation of different types of dahi}

Five types of dahi were prepared using volume reduction, add different combination of starch and potato mash with milk. Five types of dahi were designated as follows:

$\mathrm{A}=30 \%$ volume reduction (Plain dahi)

$\mathrm{B}=990 \mathrm{ml}$ milk $+1 \%$ commercial starch powder

$\mathrm{C}=980 \mathrm{ml}$ milk $+2 \%$ commercial starch powder

$\mathrm{D}=970 \mathrm{ml}$ milk $+3 \%$ commercial starch powder

$\mathrm{E}=950 \mathrm{ml}$ milk $+5 \%$ Potato mash

\section{Preparation of plain dahi}

Collected milk samples were heated to boiling temperature until reduced up to $30 \%$ of original volume milk. At the boiling time of milk, sugar was added at @ 12 per cent and stirred thoroughly with the help of stirrer. After desired heating milk pan was taken out from the heater and allowed to cool down to near $42^{\circ} \mathrm{C}$ and inoculated with $2 \%$ starter cultures collected from local market. After inoculation warm milk of $42^{\circ} \mathrm{C}$ was then poured into several pre washed plastic cups and kept in an incubation temperature of $37^{\circ} \mathrm{C}$ until complete coagulation. After complete coagulation (6-8 hrs), the dahi samples were taken out from the incubator and stored in a refrigerator at about $5^{\circ} \mathrm{C}$ for analysis.

\section{Preparation of dahi with starch without volume reduction}

The collected milk samples viz. $100 \mathrm{ml}$ raw milk $+1 \%$ starch, $100 \mathrm{ml}$ raw milk $+2 \%$ starch and $100 \mathrm{ml}$ raw milk $+3 \%$ starch was heated up to completely boiled and $12 \%$ sugar and the remaining milk mixed with the previous mixture, then heated at $75-80^{\circ} \mathrm{C}$ temperature for 30 seconds. During heating milk was stirred thoroughly with the help of a stirrer. After desired heating milk pan was taken out from the heater. The mixture was cooled at $42^{\circ} \mathrm{C}$. The starter culture (mixed culture) was added to the milk@2\%. Starter culture was mixed properly by stirring it and then milk was poured into plastic cups of around $50 \mathrm{ml}$ size and kept in incubator $\left(37^{\circ} \mathrm{C}\right)$ up to 6-8 hours. After complete coagulation, the dahi samples were taken out from the incubator and were stored in a refrigerator at low temperature $\left(5^{\circ} \mathrm{C}\right)$ until further analysis.

\section{Preparation of dahi with potato mash}

The preparation of dahi with potato mash is similar with the preparation of plain dahi. Only difference is that the prepared potato mash @ 5\% was added after heating and was blended for proper mixing and again cold down at $42^{\circ} \mathrm{C}$. At that time starter culture at the rate of $2 \%$ was added and it was kept in an incubator at $37^{\circ} \mathrm{C}$ until the complete coagulation (6-8 hrs). Then the dahi samples were stored at about $5^{\circ} \mathrm{C}$ until used.

\section{Analysis of dahi}

Physical tests (sensory and organoleptic evaluation): Dahi samples were judged individually by an expert judge team for organoleptic evaluation. Organoleptic parameters on the physical tests (sensory evaluation) measured by expert judges were as follows:

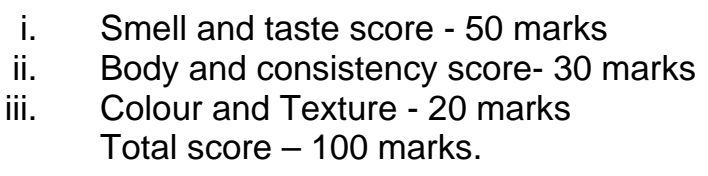

Chemical tests: The dahi samples were chemically analyzed (acidity, $\mathrm{p}^{\mathrm{H}}$, water, Fat, total solids, crude protein, carbohydrate and ash) in the laboratory. Total solids, crude protein, carbohydrate and ash content of dahi samples were estimated according to the method of AOAC (2003). Fat was estimated by Babcock method. $\mathrm{P}^{\mathrm{H}}$ of dahi sample was done by using $\mathrm{P}^{\mathrm{H}}$ meter (The $\mathrm{P}^{\mathrm{H}}$ ep Family, Hanna Instruments, made in Mauritius). 
Microbiological test: Total viable count and coliform count of different dahi samples were determined according to the method as described in the "Standard Methods for Examination of Dairy Products" American Public Health Association (APHA, 1998).

Statistical analysis: The whole experiment was conducted following Completely Randomized Design (CRD) in the laboratory. The number of treatments was five (5) and each treatment was replicated three (3) times. Data were analyzed by using one way analysis of variance test (CRD) as per SPSS statistical program using computer. The differences among sample means were compared by calculating LSD value with the help of a Least Significant Difference test (Gomez and Gomez, 1984).

\section{Results and Discussion}

The quality of prepared dahi samples were monitored with the help of different testes:

\section{Organoleptic evaluation (Physical parameters)}

Smell and taste: The smell and taste score of dahi samples A, B, C, D and E are presented in Table 1. Significant $(P<0.01)$ difference was observed among the smell and taste score of different dahi samples except between sample $A$ and $C$. The highest value was observed in sample 'A' followed by ' $C$ ', ' $B$ ' and ' $D$ ' and the lowest score was recorded in sample $E$. The variation in smell and taste score of dahi usually depends on type of milk, starter culture and manufacturing process involved (Younus, 1998). This also agrees with the findings of Akter (2004) who found that smell and taste score of dahi prepared from whole milk was higher than the samples of dahi prepared from evaporated milk.

Body and consistency: The body and consistency score of dahi samples A, B, C, D and E are presented in Table 1. The present results showed that there was a significant $(P<0.05)$ difference among A with others samples but there was no significant difference between $B$ and $C, D$ and $E$. The highest body and consistency score was seen in sample A followed by C, B and D and the lowest score was found in the sample E. It was recorded that the body and consistency score of dahi C (2\% CSP) was higher than that of $\mathrm{B}(1 \% \mathrm{CSP}), \mathrm{D}(3 \% \mathrm{CSP})$ and $\mathrm{E}(5 \%$ potato mash). The result of present findings agrees with the work of Alam (1998) who found that the addition of 25\% SM (soymilk) dahi content higher body and consistency score than other samples. The present results supported by the report of Begum (2004).

Table 1. Organoleptic evaluation (Physical Parameters) of different dahi samples

\begin{tabular}{|c|c|c|c|c|c|c|c|}
\hline \multirow{2}{*}{$\begin{array}{l}\text { Physical } \\
\text { parameters }\end{array}$} & \multicolumn{5}{|c|}{ Type of dahi } & \multirow{2}{*}{ LSD } & \multirow{2}{*}{$\begin{array}{c}\text { Level of } \\
\text { significance }\end{array}$} \\
\hline & $A$ & $B$ & C & $\mathrm{D}$ & $E$ & & \\
\hline $\begin{array}{l}\text { Smell and Taste } \\
(50)\end{array}$ & $\begin{array}{l}44.50^{\mathrm{a}} \\
\pm 0.87\end{array}$ & $\begin{array}{l}43.47^{b} \\
\pm 0.47\end{array}$ & $\begin{array}{l}44.00^{\mathrm{a}} \\
\pm 0.10^{2}\end{array}$ & $\begin{array}{l}42.47^{c} \\
\pm 0.29\end{array}$ & $\begin{array}{l}41.33^{d} \\
\pm 1.15\end{array}$ & 0.73 & ** \\
\hline $\begin{array}{l}\text { Body and consistency } \\
(30)\end{array}$ & $\begin{array}{l}27.13^{\mathrm{a}} \\
\pm 1.95 \\
\end{array}$ & $\begin{array}{l}25.33^{b} \\
\pm 1.15 \\
\end{array}$ & $\begin{array}{l}25.60^{b} \\
\pm 0.52 \\
\end{array}$ & $\begin{array}{l}24.47^{\mathrm{c}} \\
\pm 1.36 \mathrm{~b} \\
\end{array}$ & $\begin{array}{l}23.60^{\mathrm{c}} \\
\pm 1.35 \\
\end{array}$ & 1.215 & * \\
\hline Colour and texture (20) & $\begin{array}{l}17.60^{\mathrm{a}} \\
\pm 0.69\end{array}$ & $\begin{array}{c}16.23^{b c} \pm \\
0.32\end{array}$ & $\begin{array}{l}16.86^{b} \\
\pm 0.12 \\
\end{array}$ & $\begin{array}{c}15.97^{\mathrm{bc}} \\
\pm 0.25\end{array}$ & $\begin{array}{l}15.37^{c} \\
\pm 0.75\end{array}$ & 0.52 & $\star \star$ \\
\hline $\begin{array}{c}\text { Total Score } \\
(100)\end{array}$ & $\begin{array}{l}89.23^{a} \\
\pm 0.55\end{array}$ & $\begin{array}{l}85.00^{b c} \\
\pm 0.001\end{array}$ & $\begin{array}{l}86.46^{b} \\
\pm 0.20\end{array}$ & $\begin{array}{l}82.91^{\mathrm{C}} \\
\pm 0.40\end{array}$ & $\begin{array}{l}80.30^{d} \\
\pm 0.35\end{array}$ & 0.37 & ** \\
\hline
\end{tabular}

$\mathrm{A}=30 \%$ volume reduction

$\mathrm{B}=990 \mathrm{ml}$ milk $+1 \%$ commercial starch powder

$\mathrm{C}=980 \mathrm{ml}$ milk $+2 \%$ commercial starch powder

$\mathrm{D}=970 \mathrm{ml}$ milk $+3 \%$ commercial starch powder

$\mathrm{E}=950 \mathrm{ml}$ milk $+5 \%$ Potato mash

* Significant at 5\% level of probability, ** Significant at 1\% level of probability abcd Mean Values with different superscripts in the same row differ significantly, $\mathrm{P}<0.05$. 
Colour and texture: The average colour and texture score of dahi samples A, B, C, D and E are presented in Table 1. Statistical analysis showed that there was a significant difference among $A$ with others samples but there was no significant difference between $B, C$ and $D$. The highest score of colour and texture was observed in sample, A followed by C, B and D and the lowest score in sample E. The result of present study agrees with the findings of Begum (2004) who found that colour and texture score of dahi prepared from whole milk was higher than other samples.

Total score: The total score of dahi sample were given by judge on the basis of smell and taste, body and consistency and colour and texture are presented in Table 1. Statistical analysis showed that significant $(P<0.01)$ difference existed among the total score of dahi samples except for sample $B$ and $C$. The highest score was obtained by sample A followed by C, B, D and the lowest score obtained from sample E. The results of the present findings supported by Nahar (2000) and Begum (2004) who found that total score for whole milk dahi was higher than non-fat dahi samples.

\section{Chemical Parameters}

Acidity: The acidity of different dahi samples A, B, C, D and E are presented in Table 2. There was a significant difference $(P<0.01)$ among $A, B$ and $E$ but no significance difference between $B$ and $D$. Acidity increased slightly due to the addition of different levels of commercial starch powder and potato mash. This result of acidity of dahi samples agrees with the findings of Desai et al. (1994) who found that acidity of fruit dahi was significantly increased due to addition of fruit juice/pulp. Mustafa (1997) prepared dahi using different types of seasonal juice and observed that acidity content of dahi increased due to the addition of fruit juice.

$\mathbf{p}^{\mathrm{H}}$ : The $\mathrm{P}^{\mathrm{H}}$ value of different types of dahi samples are shown in Table 2. There was significant differences $(P<0.01)$ among the $P^{\mathrm{H}}$ of different dahi samples, which was highest in sample $A$ and lowest in sample E. Addition of commercial starch powder and potato mash decreased the $\mathrm{pH}$ value of dahi. The present result of the experiment agreed with the findings of Mustafa (1997) who recorded that $\mathrm{P}^{\mathrm{H}}$ of dahi decreased after addition of fruit juice.

Fat content: The fat content of different dahi samples $A, B, C, D$ and $E$ types are shown in Table 2. The results showed that there were significant $(P<0.01)$ differences between $A$ and $B$ but no significant difference among $B, C, D$ and $E$. The highest fat content was observed in sample $A$ and the lowest was in the sample E (5\% potato mash). Ghosh and Rajorhia (1987) found that fat percent of plain misty dahi varied from 4.3 to $8.8 \%$ with an average of 3.78 percent.

Protein content: The protein content of $A, B, C, D$ and $E$ types of dahi are shown in Table 2. The protein content was higher in A type plain dahi followed by C, B and D dahi and lower in E. The protein content decreased slightly due to addition of potato mash but sample $A$ is significantly different than $B, C D$ and $E$ samples. The present result agrees with the work of Mustafa et al. (1997) who found that plain dahi contain higher amount of protein than fruit dahi.

Carbohydrate content: The carbohydrate content of different dahi samples are shown in Table 2. It has be seen from the table that there was significant $(P<0.01)$ difference among $A$ with others samples but no differences between $B$ and $E, C$ and $D$ samples. The highest carbohydrate per cent was observed in sample $A$ followed by $D, C, B$, and the lowest value was recorded in sample $E$ ( $5 \%$ potato mash).

Ash content: The ash content of dahi samples A, B, C, D and E are shown in Table 2. The analysis showed that ash content of $A$ differed significantly $(P<0.01)$ from sample $B, C, D$ and $E$ where as no difference were observed between $B, C, D$ and $E$ samples. The finding of this study agrees with the work of Chakrabarty (1998) who reported that that ash content of dahi made from whole cow milk was $9.8 \pm 1.0 \mathrm{~g} / \mathrm{kg}$. 
Total solids content: The total solids content of different dahi samples A, B, C, D and E are mentioned in Table 2. There was a significant difference $(P<0.01)$ among the TS content of different types of dahi except between sample B and E. Total solids \% of sample A was higher than that of other samples. Ghosh and Rajorhia (1987) observed that total solids content of dahi varied from 269.2 to $430.4 \mathrm{~g} / \mathrm{kg}$ with an average value of $339.6 \mathrm{~g} / \mathrm{kg}$. Total solids content of dahi in this experiment was lower than the findings of the author Nahar (2000). This variation could be attributed due to use of different types of milk, addition of different concentration of sugar.

Moisture content: The moisture content of different dahi samples $A, B, C, D$ and $E$ are presented in the Table 2. The highest moisture content was observed in sample $E$ and the lowest were in the sample $A$. There was a significant difference $(P<0.01)$ between $A$ and $E, C$ and $D$ whereas no difference were observed in B and E samples. Avlesen et al. (1979) observed that a good flavour dahi contained $770 \mathrm{~g} / \mathrm{kg}$ or less water.

Table 2. Chemical and microbiological parameters of different dahi samples

\begin{tabular}{|c|c|c|c|c|c|c|c|}
\hline \multirow{2}{*}{ Chemical Parameters } & \multicolumn{5}{|c|}{ Types of dahi } & \multirow{2}{*}{$\begin{array}{l}\text { LSD } \\
\text { value }\end{array}$} & \multirow{2}{*}{$\begin{array}{c}\text { Level of } \\
\text { significance }\end{array}$} \\
\hline & $A$ & $B$ & C & D & $E$ & & \\
\hline Acidity (\%) & $0.65^{c} \pm 0.01$ & $0.68^{b} \pm 0.01$ & $0.69^{\mathrm{ab}} \pm 0.01$ & $0.68^{\mathrm{b}} \pm 0.01$ & $0.71^{\mathrm{a}} \pm 0.01$ & 0.01 & ** \\
\hline$p^{H}$ & $4.68^{\mathrm{a}} \pm 0.03$ & $4.57^{b} \pm 0.03$ & $4.52^{d} \pm 0.03$ & $4.55^{c} \pm 0.001$ & $4.50^{e} \pm 0.001$ & 0.01 & ** \\
\hline FAT $(\mathrm{g} / \mathrm{kg})$ & $54.87^{a} \pm 7.09$ & $37.77^{\mathrm{b}} \pm 4.86$ & $38.10^{\mathrm{b}} \pm 4.91 \mathrm{a}$ & $37.50^{b} \pm 4.81$ & $36.53^{b} \pm 4.71$ & 5.6 & ** \\
\hline Protein $(\mathrm{g} / \mathrm{kg})$ & $41.96^{a} \pm 2.33$ & $30.17^{b} \pm 1.59$ & $31.71^{b} \pm 1.58$ & $31.00^{b} \pm 1.56$ & $30.17^{\mathrm{b}} \pm 1.89$ & 1.9 & ** \\
\hline Carbohydrate $(\mathrm{g} / \mathrm{kg})$ & $196.66^{\mathrm{a}} \pm 2.79$ & $144.53^{d} \pm 1.97$ & $151.41^{b} \pm 1.92$ & $158.30^{b} \pm 1.91$ & $144.30^{d} \pm 2.08$ & 2.2 & ** \\
\hline Ash $(\mathrm{g} / \mathrm{kg})$ & $8.72^{a} \pm 0.33$ & $6.09^{b} \pm 0.23$ & $6.13^{b} \pm 0.22$ & $6.10^{b} \pm 0.24$ & $6.03^{b} \pm 0.06$ & 0.24 & ** \\
\hline Total Solids ( $\mathrm{g} / \mathrm{kg}$ ) & $302.20^{a} \pm 12.25$ & $218.89^{d} \pm 8.51$ & $226.30^{b} \pm 8.37$ & $233.61^{c} \pm 8.36$ & $217.03^{d} \pm 7.76$ & 9.6 & $\star *$ \\
\hline Moisture $(\mathrm{g} / \mathrm{kg})$ & $697.80^{d} \pm 12.25$ & $781.11^{\mathrm{a}} \pm 8.51$ & $773.70^{\mathrm{b}} \pm 8.37$ & $766.39^{c} \pm 8.36$ & $782.97^{\mathrm{a}} \pm 7.76$ & 9.6 & ** \\
\hline \multicolumn{8}{|l|}{ Microbial parameters } \\
\hline Coliform & $10.00 \pm 0.00$ & $16.67 \pm 5.77$ & $16.67 \pm 5.77$ & $13.33 \pm 5.77$ & $36.67 \pm 23.09$ & - & NS \\
\hline $\begin{array}{l}\text { Total viable count } \\
\left(\times 10^{4}\right)\end{array}$ & $109.00^{\mathrm{d}} \pm 6.00$ & $133.33^{\mathrm{C}} \pm 4.73$ & $142.67^{b} \pm 3.51$ & $143.0^{b} \pm 7.0$ & $176.67^{\mathrm{a}} \pm 5.86$ & 5.82 & ** \\
\hline
\end{tabular}

* Significant at $5 \%$ level of probability, ** Significant at $1 \%$ level of probability, NS = Not significant. abcd Mean Values with different superscripts in the same row differ significantly, $\mathrm{P}<0.05$.

\section{Microbiological Parameters}

Total viable count: The total viable count per $\mathrm{ml}$ of dahi samples are presented in Table 2. It was observed that there was a significant $(P<0.01)$ differences among the different types of dahi sample except between sample $C$ and $D$. The highest total viable count $/ \mathrm{ml}$ was recorded for $E$ type dahi sample which indicates that it contains more favorable condition for growth of microbes.and lowest value was recorded for A type dahi. Bacteria might have got more nutrients from commercial starch powder, and most probably less hygienic measure was taken in potato mash manufacturing.

Coliform count: The average coliform count per ml of dahi samples A, B, C, D and E are shown in Table 2. There was no significant difference among the samples. The highest coliform count was observed in sample $E$ ( $5 \%$ potato mash) followed by $B, C$ and $D$, and the lowest was recorded in sample $A$. Coliform contamination might be occurred by potato mash prepared with less hygienic measure.

From the above findings, it is observed that addition of starch powder during dahi preparation increased physical and some chemical qualities but decreased microbiological qualities. By adding starch powder (2\%), over all appearance, pleasant flavour and good colour are produced. Carbohydrate and protein content are remarkably increased by adding starch powder. 


\section{Conclusion}

Judging of different parameters of the experiment studied, it may be concluded that $2 \%$ starch powder could be used successfully for preparing dahi. So, Addition of starch powder will not only enriches the nutritive value of dahi but also make the product cheaper which may be financially profitable for the producers.

\section{References}

Akter, S. 2004. Qualitative characteristic of dahi prepared from reconstituted milk. MS Thesis, Department of Dairy Science, Bangladesh Agricultural University, Mymensingh.

Alam, S. 1998. A study on the preparation of dahi from soymilk. M.S. Thesis, Department of Dairy Science, Bangladesh Agricultural University, Mymensingh.

AOAC International. 2003. Official methods of analysis of AOAC International. 17th edition. 2nd revision. Gaithersburg, MD, USA, Association of Analytical Communities.

APHA (American Public Health Association). 1998. Standard Methods for Examination of Dairy Products. $20^{\text {th }}$ edition, Washington. D.C., USA.

Avlesen, K., Abrahmsen, R.K. and Steimstholt, K. 1979. Production of yogurt powder for acidification of frozen yogurt. Meieriposten. 68 (6): 167-170.

Begum, J. 2004. Qualitative characteristics of dahi prepared from non-fat dry milk fortified with vegetable oil. M.S. Thesis, Department of Dairy Science, Bangladesh Agricultural University, Mymensingh.

Chakrabarty, M. 1998. A study on the preparation of dahi from whole milk of cow, buffalo and their different proportionate mixtures. MS Thesis, Department of Dairy Science, Bangladesh Agricultural University, Mymensingh.

Desai, S.R., Toro, V.A. and Joshi, S. 1994. Utilization of different fruits in the manufacture of yoghurt. Indian Journal of Dairy Science. 47(10): 870-874.

Ghosh, J. and Rajorhia, G.S. 1987. Technology for production of misti dahi: A traditional fermented milk product. Indian Journal of Dairy Science. 43: 239-246.

Gomez, A.K. and Gomez, A.A. 1984. Statistical Procedure for Agricultural Research. Second Edition. John Wiley and Sons, New York. pp. 95-109

Hardi, J. and Novakovic, P. 1994. The feasibility of yoghurt manufacture using cow milk and soya milk blends. Znanost-i-Praksa-uPoljoprivaredi-i-Prehrambenoj-Tehnologiji. 22(3): 475-490.

Laxminarayana, H., Nambadripad, V.K.N., Lakshmi, N.V., Nantaramiah, S.N. and Sreenivasamurthy, V. 1952. Studies on dahi II. General Survey of the quality of market dahi. Indian Journal of Veterinary Science. 22(1): 13-17.

Mann, G.V. and Spoerry, A. 1974. Studies of a surfactant and cholesteremia in the Massai. American Journal of Clinical Nutrition. 27(5): 464-469.

Mustafa, M.M.H. 1997. A study on the preparation of fruit dahi (yoghurt). M.S. Thesis, Department of Dairy Science. Bangladesh Agricultural University, Mymensingh.

Nahar, L. 2000. Studies on the preparation of dahi (yogurt) form skim milk with the addition of vegetable oil and different levels of non-fat dry milk (NDM). M.S. Thesis, Department of Dairy Science, Bangladesh Agricultural University, Mymensingh.

Shakeel, Asga, Thompkinson, D.K. and Asgar, S. 1994. Manufacture of fruit flavoured filled bio-yogurt. Indian Journal of Dairy Science. 47(8): 698-701.

Younus, M. 1998. A comparative study on the quality of dahi (yogurt) available in Mymensingh Town. M.S Thesis, Department of Dairy Science, Bangladesh Agricultural University, Mymensingh. 